\title{
THE IMPORTANCE OF MANAGEMENT COMPETENCIES OF WORKERS AT THE MIDDLE LEVEL OF MANAGEMENT IN THE HOSPITALS
}

\author{
T. Kotrba
}

Received: July 4, 2008

\begin{abstract}
KOTRBA, T.: The importance of management competencies of workers at the middle level of management in the hospitals. Acta univ. agric. et silvic. Mendel. Brun., 2008, LVI, No. 6, pp. 47-58

This paper deals with management competencies of head and department nurses in Moravian hospitals. There are cited papers from Czech authors in the theoretical part which deal with health care, and the work of nurses. The research is based on a questionnaire sent to the hospitals in Znojmo, Třebíč and the Faculty hospital of St. Anna in Brno. Totally, the average response rate was 63,6\%, covering 886 nurses, 124 department nurses and 29 head nurses - 1039 in total. In terms of nurses' education the high school-leaving exam is most common; in average about $80 \%$ of all nurses. And this is the same for head and department nurses, where there will be a requirement for a university degree in future especially for the position head nurse. This research shows that informal relationships predominate in hospitals. This is based on the democratic managerial style of department and head nurses. They predominantly obtained knowledge from human resource management in their working practice and previous occupation, (65,9\% respondents). Nurses and especially department nurses $(66,7 \%)$ don't want to manage people but don't want to reach higher positions (I think this is what you mean) and don't reach position of their subordinate. Department nurses but head nurses would like to participate in management and human resource management courses. According to the results of this questionnaire research (evaluation of nurses and self evaluation of department nurses and head nurses as well) management competencies are on good level in analysed hospitals. By testing dependence of chosen variables was found middle strong dependence between valuables: working position by department and head nurses and their preferences of communicative relationships. By department nurses which evaluated managerial style of head nurse and satisfaction with their occupation was found middle strong dependence as well.
\end{abstract}

management, competencies, human resource management, education, management skills, qualification requirements, health care, questionnaires research

Health care is very sensitive topic today for many people. Many articles and scientific papers have been published. Hospitals play a big role as well as private doctors, specialists and clinics. Their function is considered not only from an economic point of view but from the ethical side as well. On the other hand health care workers are firstly assessed from the skilled medical viewpoint, but also from the area of soft skills that reflects the relationships to the patients. There are various researches which are dealing with the quality of health care and of satisfaction patients with the whole service of specific hospitals. The author does not deal with this area but has aimed at the topic of managers' competencies of health care workers who are working at the middle and lower level of management in the public hospitals. And these workers should have, as well as the necessary special medical skills, managerial competencies. Relations between nurse and patients reflects how nurses teams function, nurses' individual working satisfaction with their superiors and the character of human resources management in the hospital, especially in the particular departments. The aim of this paper is, on the basis of a questionnaire, to research and monitor the area of managerial competencies of head nurses and department nurses. The author hopes to describe the current situation and suggest possible recommendations. 


\section{MATERIAL AND METHODS}

Questionnaires were created and distributed to target groups in paper form: nurses, head nurses, department nurses. Nurses were asked to evaluate the managerial competencies of their superiors head nurses and department nurses. Department nurses evaluated work of their head nurse as well. And finally nurses in managers' position (department nurses and head nurses) completed a questionnaire in which they could express to their own managerial competencies. Three types of questinnaire were processed and analysed.

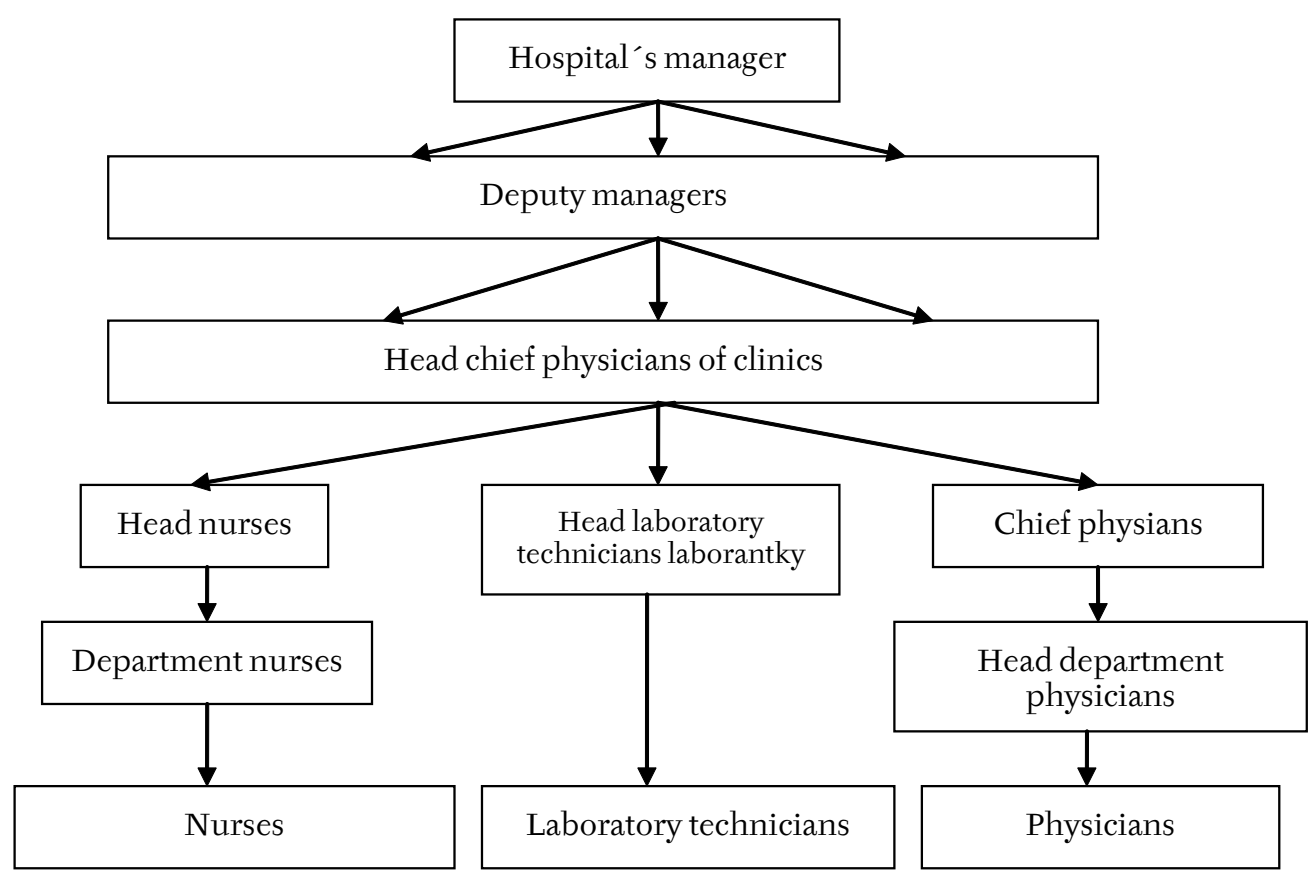

Source: Kotrba (2006), adapted to this research

1: Simplified management scheme of hospitals in the Czech Republic

Fig. 1 shows the relationships between the different levels of management in the hospital. The hospital's manager with his deputy managers and head chief physicians of clinic is counts as senior management. This paper concentrates on the middle and lower management and primarily on the positions of head nurse and department nurse. Other health care managers and workers and non medical personnel are not included in this research. For the top management of the hospitals managerial competencies are essential so the author doesn't deal with this level of management and he does not comment on the issue of whether the head of the hospital should be a doctor or an economic expert.

In the questionnaire for nurses were defined 23 closed-ended questions. Department nurses were expressed to the level of managers' competencies of head nurse in the 16 cases. Head nurses and department nurses answered the 21 questions regarding their own evaluation of managers' competencies. For the purpose of this paper questions were chosen concerned with management skills, education and qualification requirements.

Hospitals in Znojmo, Trebíč and Faculty hospital by St. Anna in Brno were included in the research.
Of the 1039 respondents 886 were nurses, 124 department nurses and 29 head nurses.

The highest response rate (in average around $64 \%$ ) was in the Faculty hospital of St. Anna in Brno, the lowest was in the hospital in Třebíč (21.5\%). Questionnaires were distributed always in the same way - personally with the author at the meeting of head and department nurses directly in the cooperating hospitals. The reason of the lower response rate in the Trebic hospital was the senior management requirement that answers should be on a departmental basis leading to a lower level of anonymity. However anonymity was guaranteed with the author personally in all hospitals. Table I shows the detailed segmentation according to the individual organizations.

The MS Excel program was used to process the data. The literary sources used are shown in the list of literature. For the purpose of this analyse were used statistical tools, calculation of coefficients $\chi^{2}, \mathrm{p}$-value, Fi, Cramer $\mathrm{V}$ and Pearson coefficient of kontingence.

\section{RESULTS AND DISCUSION}

Lámal and Bellová (2005) deal with economic analyses of health care and indicators which can com- 
I: Structure and number of respondent questionnaires research

\begin{tabular}{|c|c|c|c|c|c|c|c|c|c|c|}
\hline & 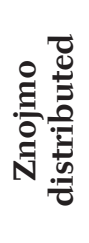 & 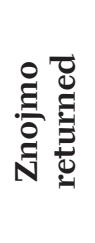 & 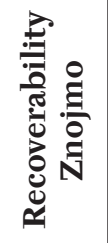 & 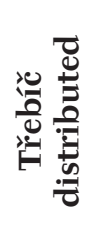 & 葛 & 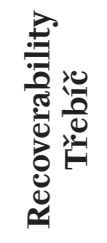 & 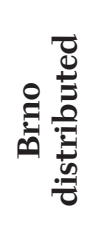 & 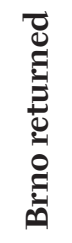 & 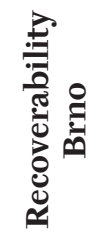 & 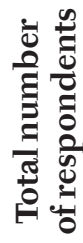 \\
\hline Head nurses & 15 & 10 & $66.7 \%$ & 18 & 5 & $27.8 \%$ & 16 & 14 & $87.5 \%$ & 29 \\
\hline Head department nurses & 26 & 17 & $65.4 \%$ & 25 & 14 & $56.0 \%$ & 97 & 93 & $95.9 \%$ & 124 \\
\hline Nurse & 327 & 177 & $54.1 \%$ & 395 & 75 & $19.0 \%$ & 1053 & 634 & $60.2 \%$ & 886 \\
\hline Total numbers & 368 & 204 & $55.4 \%$ & 438 & 94 & $21.5 \%$ & 1166 & 741 & $63.6 \%$ & 1039 \\
\hline
\end{tabular}

Source: Own research

parare individual hospitals among themselves. Souček (2007b) published on the same topic a paper in which he dealt with the issue if we can compare hospitals with commercial firms from the other sectors of the economy.

Bodison (2006) wrote that for achieving the excellent output is very important synchronization of all processes as: patient's experience, clinical results, quality and satisfaction of personal in hospital, systems of remuneration, organizational structure and financial output. Košturiak (2007) deals with contribution of health care to society and increasing of health care value from the scope of patient.

Prymula, Beran, Antoš (1999) suggest a system of continual evaluation of the quality of the work force employed. Monitoring can show very exactly job of each employee, the range of work tasks according to timetable in the relations to the qualification and optimalization of demands for qualification and number of the workforce.

Truneček (2007) compares workers in health care to knowledge workers. The profession of nurse has been historically developed from non-trained staff. There were developments in the area of various types of nurse as stated by Prymula, Beran, Antoš (1999). They recommend changing the ratio between helping nurses and qualified nurses. The nursing education system is not perfect from the viewpoint of managing work and it should be reformed in future.

Bártlová (2006b) in her paper wrote that nursing activities are changing as are their competencies and specialities. The nurse should become an independent specialist and a more equal member of health care teams in future. Exnerová (2006) enumerates competencies needed in the work of a nurse. The author divides competencies into two categories: technical and psychological competencies. Souček (2007a) in his paper adds that many problems in public health care institutions are caused with the lower level of management knowledge. The difference between medical knowledge (that is very good and in the most cases excellent) and management knowledge is a big gap. He suggests increased managerial qualifications for a wide spectrum of workers in health care. In the next paper Souček (2007c) raises the issue of the knowledge base of health care workers from the area of economy, finance and management which area is still on the fringe of interest compared to continual lifelong intensive study of special medical methods.

Nurses can very significantly influence the quality of care through alternative approachs as mentioned by Prymula, Beran, Špliňo and Antoš (1995). The nurse becomes a manager and according to her position in hiearchy of the organization she should obtain quivalent education as well. In the opinion of the authors the managerial role is increasing in significance.

Kvapilová and Jobánková (2006) wrote that satisfaction with the range of managerial competencies falls with the level of management position. Workers in the position of head nurse are the most satisfied and department nurses have the lowest satisfaction.

Specialists dealing with the topic of managerial competencies are very ambiguous. Each author has a different definition and classification of competencies. Some authors divide competencies according to soft standpoints (these are the personal characteristics that employees have in their roles) and hard standpoints (there are more measurable outputs of work such as profit, value of stock, turnover, sales amount...) as wrote Kotrba (2006).

Bártlová (2006b) published very interesting research in which she wrote that evaluation of the atmosphere in the workplace of a nurse in the Czech Republic is very good because $2 / 3$ respondents (nurses) evaluate it as friendly and cooperative. The most common problems in the relationships between doctor and nurse have roots in working overload. Secondly nurses asserted activities that are in competencies somebody else. The next reason is disparagement of nursing work from the doctors.

The next research from Bártlová (2006a) evaluated cooperation with management and the area of information passing. Nurses evaluate feeling of certainty, motivation and work evaluation as the worst in Tab. II.

Kvapilová and Jobánková (2006) mentioned that nurses in the position of department nurse face more demands and these workers feel their competencies 
are more limited. Department and head nurses very often miss the possibility of participation in the solution of critical incidents that grow up in the con- nection with violating working competencies. In the next tab (Tab. II.) is the evaluation of health care cooperation with management.

II: Evaluation of healt care cooperation with management

\begin{tabular}{|l|c|c|c|c|c|c|}
\hline & Very good & $\begin{array}{c}\text { Rather } \\
\text { good }\end{array}$ & Adeqate & $\begin{array}{c}\text { Rather } \\
\text { bad }\end{array}$ & Very bad & Average \\
\hline Leading area & $18.0 \%$ & $37.6 \%$ & $38.4 \%$ & $4.8 \%$ & $1.1 \%$ & $2.3333 \%$ \\
\hline Controling area & $11.4 \%$ & $28.1 \%$ & $54.5 \%$ & $4.9 \%$ & $1.1 \%$ & $2.5616 \%$ \\
\hline Way of information handing & $17.0 \%$ & $41.4 \%$ & $29.2 \%$ & $11.2 \%$ & $1.2 \%$ & $2.3805 \%$ \\
\hline Motivation, work evaluation & $7.4 \%$ & $22.6 \%$ & $36.7 \%$ & $27.0 \%$ & $6.4 \%$ & $3.0240 \%$ \\
\hline Giving of feeling of certainty & $9.1 \%$ & $24.4 \%$ & $41.8 \%$ & $18.6 \%$ & $6.1 \%$ & $2.8825 \%$ \\
\hline
\end{tabular}

Source: Bártlová (2006a)

Nurses very often wrote that they are faced with tasks of an administrative character from nursing management such as writing reports, statements, sheets, inventorying of property, introduce training of new workers. We can state that nurses in the Czech Republic perfom tasks that are in the jobsheet of helpers or less qualified personel (hospital attendants, orderlies, cleaners and charwomen). Nursing management in this way substitutes for insufficient helping personel as mentioned by Bártlová (2006a).
The following two tables represent the highest level of education nurses, department nurses and head nurses in the analysed hospitals.

The values in all analysed organizations are not very different. Nurses have more high school with school-leaving exam. Recently college education has been rising confirming Kotrba's (2008) analysis which dealt with the offer of management courses at the high school, colleges and primary at the medical faculties in the Czech Republic.

III: The highest level of education (nurses)

\begin{tabular}{|l|r|r|r|r|r|r|}
\hline \multirow{2}{*}{} & \multicolumn{2}{|c|}{ Znojmo } & \multicolumn{2}{c|}{ Třebíč } & \multicolumn{2}{c|}{ Brno } \\
\cline { 2 - 7 } & AF $^{1}$ & \multicolumn{1}{|c|}{$\mathbf{R F}^{2}$} & \multicolumn{1}{c|}{ AF } & \multicolumn{1}{c|}{ RF } & \multicolumn{1}{c|}{ AF } & \multicolumn{1}{c|}{ RF } \\
\hline High school & 148 & $83.6 \%$ & 60 & $81.1 \%$ & 512 & $81.4 \%$ \\
\hline Upper level of high school (college) & 26 & $14.7 \%$ & 13 & $17.6 \%$ & 88 & $14.0 \%$ \\
\hline University degree (Bc.) & 3 & $1.7 \%$ & 0 & $0.0 \%$ & 26 & $4.1 \%$ \\
\hline University degree (Mgr.) & 0 & $0.0 \%$ & 1 & $1.4 \%$ & 3 & $0.5 \%$ \\
\hline Total & 177 & $100.0 \%$ & 74 & $100.0 \%$ & 629 & $100.0 \%$ \\
\hline
\end{tabular}

Source: Own research

IV: The highest level of education (department and head nurses)

\begin{tabular}{|l|r|r|r|r|r|r|}
\hline \multirow{2}{*}{} & \multicolumn{2}{|c|}{ Znojmo } & \multicolumn{2}{c|}{ Třebíč } & \multicolumn{2}{c|}{ Brno } \\
\cline { 2 - 7 } & AF & \multicolumn{1}{|c|}{ RF } & AF & \multicolumn{1}{c|}{ RF } & \multicolumn{1}{c|}{ AF } & RF \\
\hline High school & 24 & $88.9 \%$ & 7 & $77.8 \%$ & 70 & $76.9 \%$ \\
\hline Upper level of high school (college) & 3 & $11.1 \%$ & 2 & $22.2 \%$ & 14 & $15.4 \%$ \\
\hline University degree (Bc.) & 0 & $0.0 \%$ & 0 & $0.0 \%$ & 5 & $5.5 \%$ \\
\hline University degree (Mgr.) & 0 & $0.0 \%$ & 0 & $0.0 \%$ & 2 & $2.2 \%$ \\
\hline Total & 27 & $100.0 \%$ & 9 & $100.0 \%$ & 91 & $100.0 \%$ \\
\hline
\end{tabular}

Source: Own research 
A very similar situation exists in managers' positions: head nurses and department nurses. Almost $80 \%$ of head and department nurses (101 nurses) have only high school level of education, 15\% (19 nurses) has upper level of high school (college) and only $5.5 \%$ (7 nurses) has university degree bachelor

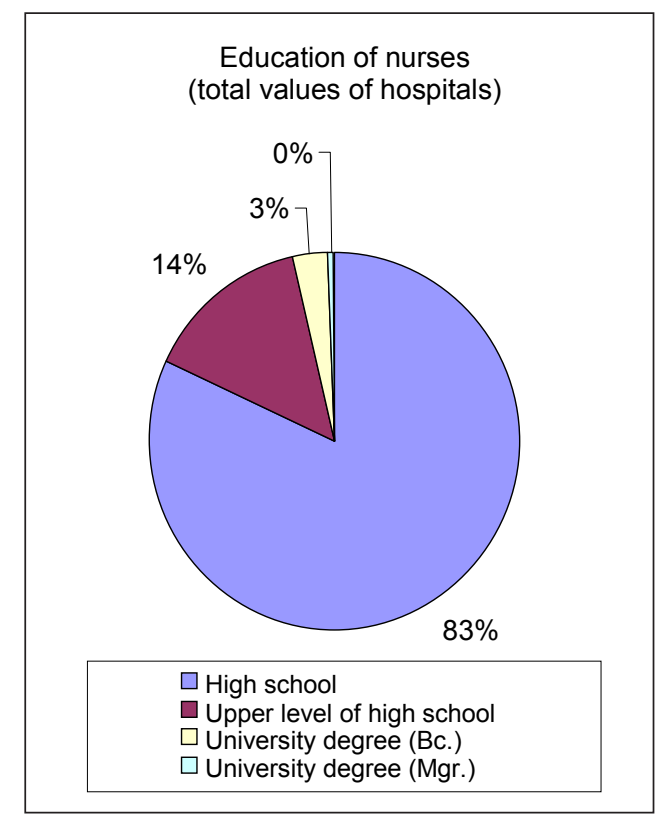

Source: Own research or master level. Among respondens from Znojmo and Třebíč no one had a university master level degree. Kotrba (2008) wrote that in these positions should work only university degree nurses in future. The education structure is shown in the next two graphs.

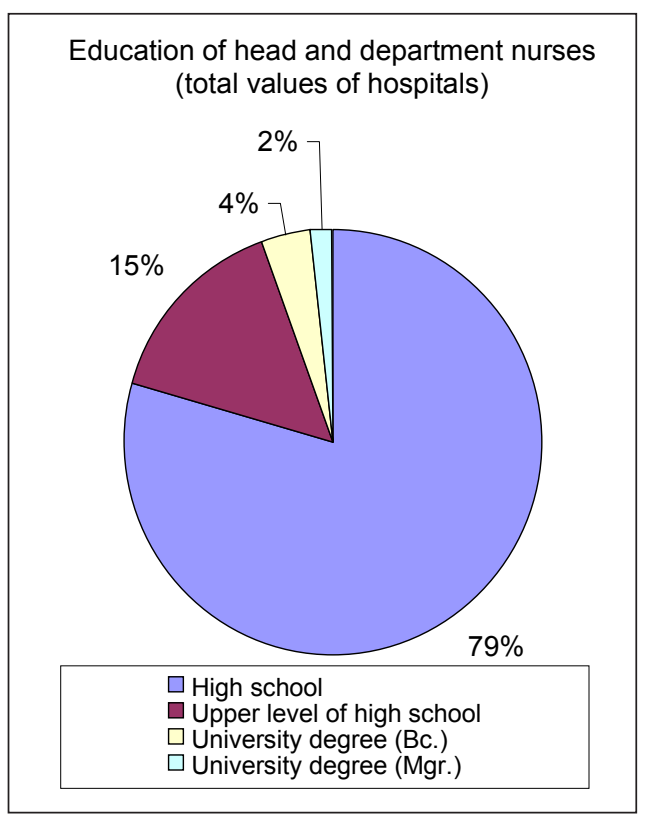

2, 3: Comparison of education on the positions of head nurses and department nurses

From Fig. 2 and 3 we can see almost the same structure of education in all positions of health care personel in the analysed hospitals. High school education with school-leaving exam still predominates but this will not be sufficient for those applying for management positions in the future.

Whilst a university degree is considered desirable for those seeking promotion to department nurse, length of service is thought more important. A different situation applies in the case of a head nurse who is chosen by a base selection procedure. A uni-

versity degree isn 't a necessary condition as noted in a paper Kotrba and Rak (2008).

There isn't dependence between variables working position (Tab I.) and the highest level of education by department and head nurses (Tab. IV.) $\left(\chi^{2}=7.6155\right.$, pvalue $=0.2676, \mathrm{Fi}=0.2175$, Cramer V $=0.1538$, Pearson coefficient of kontingence $=0.2125$ )

In the hospitals there is little difference in the case of totally length of practice for head and department nurses and there is predominating length of practice of more then 5 years (in $98.4 \%$ cases). Nurses are more varied as we can see in the following Tab. V.

$\mathrm{V}$ : The years of practice (nurses)

\begin{tabular}{|l|c|c|c|c|c|c|}
\hline & \multicolumn{2}{|c|}{ Znojmo } & \multicolumn{2}{c|}{ Třebíć } & \multicolumn{2}{c|}{ Brno } \\
\cline { 2 - 7 } & AF & RF & AF & RF & AF & RF \\
\hline Do 1-2 years (0; 2 & 14 & $7.9 \%$ & 11 & $14.9 \%$ & 73 & $11.6 \%$ \\
\hline Over 2-5 years (2; 5) & 27 & $15.3 \%$ & 8 & $10.8 \%$ & 130 & $20.7 \%$ \\
\hline Over 5 years > 5 years & 136 & $76.8 \%$ & 55 & $74.3 \%$ & 426 & $67.7 \%$ \\
\hline Total & 177 & $100.0 \%$ & 74 & $100.0 \%$ & 629 & $100.0 \%$ \\
\hline
\end{tabular}

Source: Own research

Over $70 \%$ of nurses (617 nurses) on average from all hospitals have practice in health care of over 5 years. 18.1\% (165 nurses) have practice in the range of 2 to 5 years. Only $11 \%$ (98 nurses) works less then 2 years in health care. 
There isn't dependence between variables working positron department and head nurses (Tab I.) and the years of practice of this workers $\left(\chi^{2}=0.2415\right.$, $\mathrm{p}$-value $=0.8863, \mathrm{Fi}=0.0438$, Cramer $\mathrm{V}=0.0438$, Pearson coefficient of contingence $=0.0437$ ).

Working relations have rather a informal character in the hospitals (77.2\%, 677 nurses) as evidentced by results from respondents from all three hospitals. Head and department nurses evaluated relationships as informal in $81.1 \%$ cases (103 nurses).

Results by individual hospitals do not differ. Using of informal and formal relations by communication from the position superior is in the following Tab. VI.

VI: The preferencies of head and department nurses by comunation with their inferiors

\begin{tabular}{|l|c|c|c|c|c|c|}
\hline \multirow{2}{*}{} & \multicolumn{2}{|c|}{ Znojmo } & \multicolumn{2}{c|}{ Třebíč } & \multicolumn{2}{c|}{ Brno } \\
\cline { 2 - 7 } & AF & RF & AF & RF & AF & RF \\
\hline Informal relationships & 16 & $61.5 \%$ & 6 & $66.7 \%$ & 72 & $82.8 \%$ \\
\hline Formal relationships & 10 & $38.5 \%$ & 3 & $33.3 \%$ & 15 & $17.2 \%$ \\
\hline Total & 26 & $100.0 \%$ & 9 & $100.0 \%$ & 87 & $100.0 \%$ \\
\hline
\end{tabular}

Source: Own research

Head and department nurses in 77\% cases (94 respondents) prefer informal communication to formal. The evaluation of informal communication was very similar by nurses in all the hospitals. From this fact we can assume that relationships among health care personel are rather based on informal relations and communication has a friendly character in hospitals. 680 nurses (totally $77.5 \%$ cases) agree with this opinion.

Department nurses in communication with head nurse prefer informal relations as well but 36.1\% (41 department nurses) prefer formal relations.

There was found middle strong dependence between variables working positron department and head nurses (Tab I.) and preferencies relationships among health care personel (Tab. VI.) $\left(\chi^{2}=17.6305\right.$, $\mathrm{p}$-value $=0.0001, \mathrm{Fi}=0.3801$, Cramer $\mathrm{V}=0.3801$,
Pearson coefficient of contingence $=0.3553$ ). Head nurses in 14 cases prefer formal relationships and in 13 cases informal cases. Department nurses definitely prefer in 81 cases informal relationships nad only in 14 cases formal relationships. There are concrete results by individual hospitals in next Tab. VII.

The managerial styles are connected with their relations in organizations. Nurses evaluated managerial style of department nurses as democratic (in average from all hospitals $67.5 \%, 595$ answers), a combination of all managerial styles evaluated $17.5 \%$ nurses (154 answers), and authoritative managerial style was chosen by $12.1 \%$ (107 answers). Detailed results by hospitals are in following Tab. VIII.

The very similar results form department nurses is in following Fig. 4. They evaluated managerial style of their head nurse.

VII: The preferencies of department nurses in communication with head nurse

\begin{tabular}{|l|c|c|c|c|c|c|}
\hline \multirow{2}{*}{} & \multicolumn{2}{|c|}{ Znojmo } & \multicolumn{2}{c|}{ Třebíč } & \multicolumn{2}{c|}{ Brno } \\
\cline { 2 - 7 } & AF & RF & AF & RF & AF & RF \\
\hline Informal relationships & 12 & $66.7 \%$ & 12 & $85.7 \%$ & 54 & $60.0 \%$ \\
\hline Formal relationships & 6 & $33.3 \%$ & 2 & $14.3 \%$ & 36 & $40.0 \%$ \\
\hline Total & 18 & $100.0 \%$ & 14 & $100.0 \%$ & 90 & $100.0 \%$ \\
\hline
\end{tabular}

Source: Own research

VIII: The evaluation of managerial style of department nurses from the position nurses

\begin{tabular}{|l|r|r|r|r|r|r|}
\hline \multirow{2}{*}{} & \multicolumn{2}{|c|}{ Znojmo } & \multicolumn{2}{c|}{ Třebíč } & \multicolumn{2}{c|}{ Brno } \\
\cline { 2 - 7 } & \multicolumn{1}{|c|}{ AF } & \multicolumn{1}{c|}{ RF } & \multicolumn{1}{c|}{ AF } & \multicolumn{1}{c|}{ RF } & \multicolumn{1}{c|}{ AF } & \multicolumn{1}{c|}{ RF } \\
\hline Autoritative & 20 & $11.4 \%$ & 14 & $18.9 \%$ & 73 & $11.6 \%$ \\
\hline Democratic & 124 & $70.5 \%$ & 51 & $68.9 \%$ & 420 & $66.5 \%$ \\
\hline Liberal & 9 & $5.1 \%$ & 0 & $0.0 \%$ & 17 & $2.7 \%$ \\
\hline Combination of all styles & 23 & $13.1 \%$ & 9 & $12.2 \%$ & 122 & $19.3 \%$ \\
\hline Total & 176 & $100.0 \%$ & 74 & $100.0 \%$ & 632 & $100.0 \%$ \\
\hline
\end{tabular}

Source: Own research 


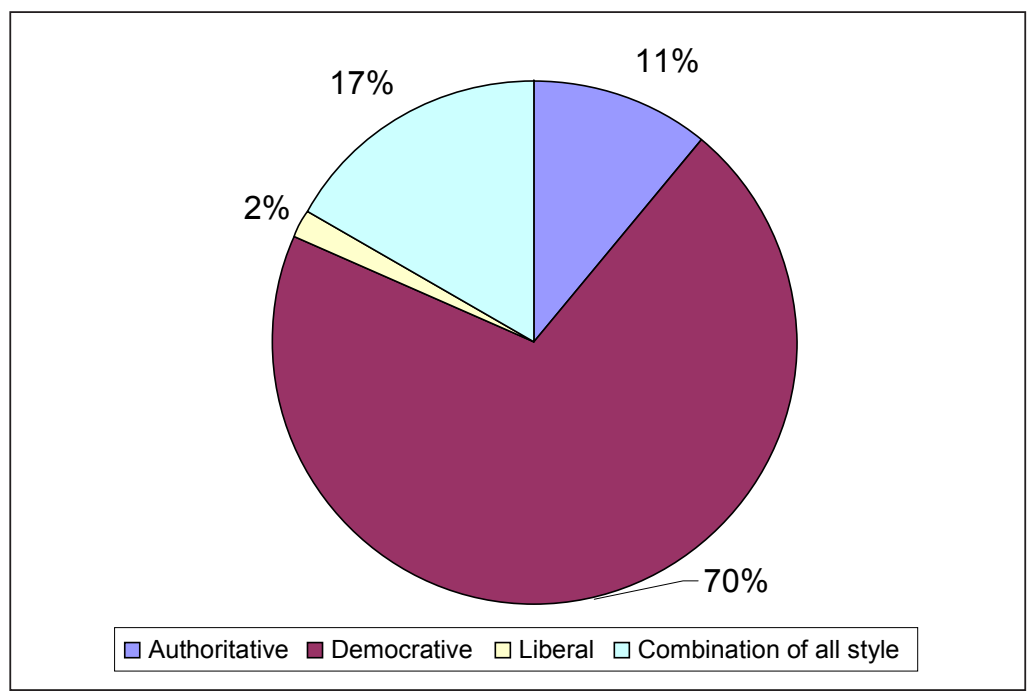

Source: Own research

4: Evaluation of managerial style of head nurses by department nurses in hospitals

By testing of dependence between evaluation of managerial style of head nurses by department nurses (Fig. 4) an satisfaction with the working output of head nurses was found middle strong dependence $\left(\chi^{2}=53.9777\right.$, $p$-value $=0.0000, \mathrm{Fi}=0.6942$, Cramer V $=0.4008$, Pearson coefficient of kontingence $=0.5703)$. Department nurses, who are with working output of head nurse definitely satisfied, agreed in 7 cases with authoritative managerial style, in 74 cases with democratic managerial style and finally 10 respondents agreed with combination of all styles. Rather satisfied were department nurses with democratic managerial style (14 cases), in 2 cases with authoritative, in 11 cases with combination of all managerial style and only one respondent was satisfied with liberal managerial style. Rather nonsatisfied were nurses with authoritative managerial style in 5 cases and with liberal style in 1 case.

The same question was put to head nurses and department nurses. They should evaluate their own managerial style that they mainly use. In the most cases head and deparment nurses believe that their managerial style is democratic (87.2\%, 109 nurses), only $4.0 \%$ (5 nurses) said that they use an authoritative managerial style and 8.8\% (11 nurses) mainly combine all managerial styles. Noboady chose the liberal managerial style.

There isn't dependence between variables working positron department and head nurses (Tab I.) and self evaluation of choice managerial style of subordintates. $\left(\chi^{2}=1.3676\right.$, p-value $=0.8498, \mathrm{Fi}=0.1046$, Cramer $\mathrm{V}=0.0740$, Pearson coefficient of contingence $=0.1040$ ).

Almost all nurses from analysed hospitals (95.4\%, 841 answers) assume that management skills in the work of department nurses are necessary for this position. Department nurses (96.1\%, 122 answers) thought the same. They realize they need management skills for their work. Answers in the hospitals were almost the same. The evaluation of management skills of department nurse is in next Tab. IX.

IX: Evaluation of management skills of department nurses

\begin{tabular}{|l|r|r|r|r|r|r|}
\hline \multirow{2}{*}{} & \multicolumn{2}{|c|}{ Znojmo } & \multicolumn{2}{c|}{ Tŕebíč } & \multicolumn{2}{c|}{ Brno } \\
\cline { 2 - 7 } & AF & \multicolumn{1}{|c|}{ RF } & \multicolumn{1}{c|}{ AF } & \multicolumn{1}{c|}{ RF } & \multicolumn{1}{c|}{ AF } & RF \\
\hline She controls perfectly, without problems & 143 & $89.9 \%$ & 58 & $77.3 \%$ & 502 & $79.8 \%$ \\
\hline She controls, but with troubles & 5 & $3.1 \%$ & 14 & $18.7 \%$ & 114 & $18.1 \%$ \\
\hline She doesn't control, but she wants it change & 0 & $0.0 \%$ & 0 & $0.0 \%$ & 4 & $0.6 \%$ \\
\hline She doesn't control and she doesn't want it change & 11 & $6.9 \%$ & 3 & $4.0 \%$ & 9 & $1.4 \%$ \\
\hline Total & 159 & $100.0 \%$ & 75 & $100.0 \%$ & 629 & $100.0 \%$ \\
\hline
\end{tabular}

Source: Own research

Similarly answered department nurses (99.2\%, 122 answers) to the issue if head nurses nead for they work management skills. In average $90 \%$ of depart- ment nurses (87.2\%, 109 answers) agreed on the fact that their head nurse have management skills and she manages it perfectly, without problems. Only 6 nurses 
from hospital in Brno wrote that head nurse management skills hasn't and she isn't interested to change it.

In the selfevaluation questionnaire head and department nurses wrote that they are rather satisfied with own management skills (59.7\%, 74 answers). $21 \%$ nurses answered that they can't assume their own management skills. The last common answer was in $13.7 \%$ case definitely satisfaction with own level of management skills. So, total satisfaction with own management skills is $73.4 \%$. Deatiled structure of respondents answer by hospitals is in following Tab. X.
From the area of human resources management most nurses have choosen (410 answers, $37.1 \%$ ), that they have experience from their own working practice and previous jobs. 23.6\% nurses answered that they have basic knowledge from the school. Almost the same percentage of nurses (20.6\%) said they don't have basic knowledge from school. And finally $18.7 \%$ nurses have basic knowledge from training. Nurses can mark more than one answer to this question. Detailed results by hospitals are shown in the following Tab. XI.

X: Self-evaluation of management skills of department nurses

\begin{tabular}{|l|r|r|r|r|r|r|}
\hline \multirow{2}{*}{} & \multicolumn{2}{|c|}{ Znojmo } & \multicolumn{2}{c|}{ Tř́bíc } & \multicolumn{2}{c|}{ Brno } \\
\cline { 2 - 7 } & AF & \multicolumn{1}{c|}{ RF } & \multicolumn{1}{c|}{ AF } & \multicolumn{1}{c|}{ RF } & \multicolumn{1}{c|}{ AF } & \multicolumn{1}{c|}{ RF } \\
\hline Definitely satisfied & 4 & $15.4 \%$ & 0 & $0.0 \%$ & 13 & $14.6 \%$ \\
\hline Rather satisfied & 14 & $53.9 \%$ & 8 & $88.9 \%$ & 52 & $58.4 \%$ \\
\hline Rather non-satisfied & 1 & $3.9 \%$ & 0 & $0.0 \%$ & 5 & $5.6 \%$ \\
\hline Definitely not-satisfied & 0 & $0.0 \%$ & 0 & $0.0 \%$ & 1 & $1.1 \%$ \\
\hline I can't consider & 7 & $26.9 \%$ & 1 & $11.1 \%$ & 18 & $20.2 \%$ \\
\hline Total & 26 & $100.0 \%$ & 9 & $100.0 \%$ & 89 & $100.0 \%$ \\
\hline
\end{tabular}

Source: Own research

XI: Sources for obtaining knowledge from human resources management

\begin{tabular}{|l|c|c|c|c|c|c|}
\hline \multirow{2}{*}{} & \multicolumn{2}{|c|}{ Znojmo } & \multicolumn{2}{c|}{ Třebíc } & \multicolumn{2}{c|}{ Brno } \\
\cline { 2 - 6 } & AF & RF & AF & RF & AF & RF \\
\hline I have basic knowledge from the school & 67 & $29.0 \%$ & 22 & $24.2 \%$ & 172 & $21.9 \%$ \\
\hline I have basic knowledge from on-the-job training & 44 & $19.0 \%$ & 17 & $18.7 \%$ & 146 & $18.6 \%$ \\
\hline I have basic knowledge from practise, my job experience & 77 & $33.3 \%$ & 34 & $37.4 \%$ & 299 & $38.1 \%$ \\
\hline I don't have basic knowledge from the school & 43 & $18.6 \%$ & 18 & $19.8 \%$ & 167 & $21.3 \%$ \\
\hline Total & 231 & $100.0 \%$ & 91 & $100.0 \%$ & 784 & $100.0 \%$ \\
\hline
\end{tabular}

Source: Own research

If nurses have chosen school, they were asked for the type of school in which they think that helped them from the scope of knowledge from human resources management. They mostly mark high school (238 nurses, $65.9 \%$ ), 87 nurses (24.1\%) answered college and only $10 \%$ of nurses have chosen university. Answers were inconsistent with the higher achieved education of nurses as is evident from Tab. III.

The situation was similar for department and head nurses - high school degrese predomites. 45.2\% (94 nurses) said that they have basic knowledge of human resource management from their own practice almost 40\% (82 nurses) have chosen training and only $12 \%$ (25 nurses) from school. A detailed division by hospitals is shown in Fig. 5.

Department and head nurses again have chosen high school (60.5\%, 26 answers), then college $23.3 \%$ (10 answers) and finally university $16.3 \%$ (7 answers).
It corresponds with the structure of higher achieved education by head and department nurses (Tab. IV). But according to previous analysis Kotrba (2008) the situation at the universities is different. At high school teaching of management wholly on the boudaries. Nobody assumes that graduates will work in management positions. The situation is better at colleges and at universities. There management is included in more courses.

According this research almost $80 \%$ of nurses (79.6\%, 681 respondents) do not want to manage people and be in a management position. Only 98 nurses (11.4\%) would like to reach the position of department or head nurse. They assume as well that they haven't for this position preconditions. Detailed division by hospitals is shown in the following Tab. XII. 


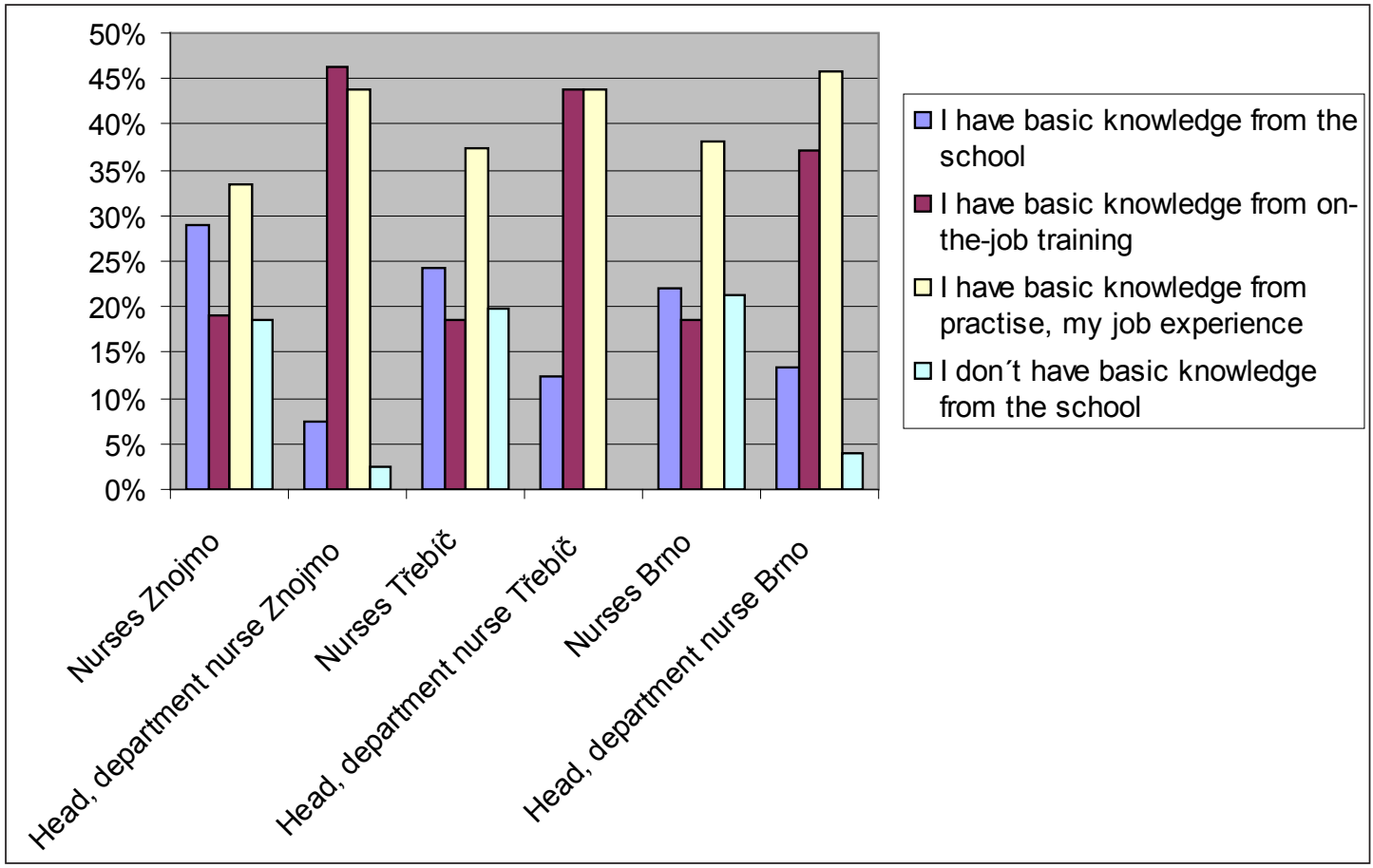

Source: Own research

5: Sources of management skills

XII: Do you want to work at the positron of your superior (department nurse) in future?

\begin{tabular}{|l|r|r|r|r|r|r|}
\hline \multirow{2}{*}{} & \multicolumn{2}{|c|}{ Znojmo } & \multicolumn{2}{c|}{ Třebíc } & \multicolumn{2}{c|}{ Brno } \\
\cline { 2 - 7 } & AF & RF & AF & \multicolumn{1}{c|}{ RF } & \multicolumn{1}{c|}{ AF } & RF \\
\hline $\begin{array}{l}\text { Reach position of department nurse, I have } \\
\text { preconditions for this. }\end{array}$ & 11 & $6.5 \%$ & 4 & $5.4 \%$ & 62 & $10.1 \%$ \\
\hline $\begin{array}{l}\text { Reach position of department nurse, I haven't } \\
\text { preconditions for this. }\end{array}$ & 8 & $4.7 \%$ & 9 & $12.2 \%$ & 81 & $13.2 \%$ \\
\hline I don't want to manage people. & 150 & $88.8 \%$ & 61 & $82.4 \%$ & 470 & $76.7 \%$ \\
\hline Total & 169 & $100.0 \%$ & 74 & $100.0 \%$ & 613 & $100.0 \%$ \\
\hline
\end{tabular}

Source: Own research

There were very interesting results from department nurses which wrote that they don't want to manage people (66.7\% cases, 74 respondents). They have chosen this answer even though they are managing people in their position currently. Only 14 nurses venture on work of the head nurse. They thing they have for this work preconditions. On the other hand 23 nurses (20.7\%) would like to work on this position, but they think that they have not got the preconditions. Detailed division by hospitals is shown the next Tab. XII.

XIII: Do you want to work at the positron of your head nurse in future?

\begin{tabular}{|l|c|c|c|c|c|c|}
\hline & \multicolumn{2}{|c|}{ Znojmo } & \multicolumn{2}{c|}{ Tŕebíč } & \multicolumn{2}{c|}{ Brno } \\
\cline { 2 - 6 } & AF & RF & AF & RF & AF & RF \\
\hline $\begin{array}{l}\text { Reach position of department nurse, I have } \\
\text { preconditions for this. }\end{array}$ & 1 & $6.3 \%$ & 1 & $7.7 \%$ & 12 & $14.6 \%$ \\
\hline $\begin{array}{l}\text { Reach position of department nurse, I haven't } \\
\text { preconditions for this. }\end{array}$ & 1 & $6.3 \%$ & 2 & $15.4 \%$ & 20 & $24.4 \%$ \\
\hline I don't want manage people. & 14 & $87.5 \%$ & 10 & $76.9 \%$ & 50 & $61.0 \%$ \\
\hline Total & 16 & $100.0 \%$ & 13 & $100.0 \%$ & 82 & $100.0 \%$ \\
\hline
\end{tabular}

Source: Own research 
Education of workers is connected with knowledge. More then 50\% nurses (58.3\%, 507 respondents) are not interested in management courses. In evaluating education, 500 department nurses (59.0\%) wrote that their superior should have more training in human resource management.

Head and department nurses agreed on this statement, because they wrote, they are interested in management courses. Totally 104 nurses (86.7\%) would like to participate in this. The most interested were department and head nurses from Faculty hospital by St. Anna in Brno, as is shown in the next Tab. XIV.

There were very similar answers from department nurses regarding education of head nurses (in next Tab. XV).

XIV: Offer of management courses for head and department nurses

\begin{tabular}{|l|c|c|c|c|c|r|}
\hline \multirow{2}{*}{} & \multicolumn{2}{|c|}{ Znojmo } & \multicolumn{2}{c|}{ Třebíč } & \multicolumn{2}{c|}{ Brno } \\
\cline { 2 - 7 } & AF & RF & AF & \multicolumn{1}{c|}{ RF } & \multicolumn{1}{c|}{ AF } & RF \\
\hline I am interested in management courses. & 17 & $73.9 \%$ & 7 & $77.8 \%$ & 80 & $90.9 \%$ \\
\hline I am not interested in management courses. & 6 & $26.1 \%$ & 2 & $22.2 \%$ & 8 & $9.1 \%$ \\
\hline Total & 23 & $100.0 \%$ & 9 & $100.0 \%$ & 88 & $100.0 \%$ \\
\hline
\end{tabular}

Source: Own research

XV: Should your head nurse be more educated?

\begin{tabular}{|l|c|c|c|c|c|c|}
\hline \multirow{2}{*}{} & \multicolumn{2}{|c|}{ Znojmo } & \multicolumn{2}{c|}{ Třebíč } & \multicolumn{2}{c|}{ Brno } \\
\cline { 2 - 7 } & AF & RF & AF & RF & AF & RF \\
\hline Yes & 9 & $52.9 \%$ & 7 & $53.8 \%$ & 54 & $65.1 \%$ \\
\hline No & 8 & $47.1 \%$ & 6 & $46.2 \%$ & 29 & $34.9 \%$ \\
\hline Totally & 17 & $100.0 \%$ & 13 & $100.0 \%$ & 83 & $100.0 \%$ \\
\hline
\end{tabular}

Source: Own research

Managerial competencies of workers on the middle and lower level of management in analysed hospitals are on the good level. According to these research informal relations, friendly atmosphere and informal communication predominate. Nurses mostly use a democratic managerial style. There are not big differences in the answers given to most questions in the hospitals analysed. Though head and department nurses judge their managerial competences positivel, nevertheless they should undertake further education in management.

\section{SOUHRN}

Důležitost manažerských kompetencí pracovníků na střední úrovni řízení v nemocnicích Vedle odborných předpokladů v současné době nabývají na významu také dovednosti a znalosti z oblasti měkkých dovedností, ale také na managementu. Článek se zabývá manažerskými kompetencemi pracovníků ve zdravotnictví. Cílovými skupinami byly zdravotní sestry, které zastávají manažerské pozice na stř̌ední a nižší úrovni řízení ve veřejných nemocnicích.

Z hlediska nejvyššího dosaženého vzdělání se struktura v analyzovaných nemocnicích př́liš neliší. Jak u všeobecných, tak u vrchních a staničních sester převažuje středoškolské vzdělání, v průměru kolem 80\%. Podíl vysokoškolsky vzdělaného personálu je dle výzkumu velice malý a v budoucnu bude nedostatečný z důvodu vyšších požadavků na řídicí pozice. Lepší situace je u délky praxe cílových skupin. Více jak 70\% zdravotních sester má ve zdravotnictví delší praxi než 5 let. Pracovní vztahy na pracovištích mají spíše neformálních charakter, na čemž se shodly jak sestry, tak staniční i vrchní sestry ve všech nemocnicích. Řídicí pracovníci navíc dodali, že v 81,1\% (103 sester) preferují neformální vztahy při komunikaci se svými podřízenými. Při komunikaci staničních sester s hlavními sestrami byla situace podobná, avšak zde již 36,1 \% (41 staničních sester) preferuje formální styl komunikace. Styl řízení staničních sester je dle názoru sester v 67,7\% (595 sester) demokratický. Na tomto stanovisku se shodly také vrchní i staniční sestry, které uvedly, že převážně používají demokratický styl řízení (87,2\%, 109 vrchní a staničních sester). S řídicími dovednostmi svých nadřízených jsou spokojené jak zdravotní sestry, tak staniční sestry. Staniční i vrchní sestry jsou ve většině případů (celkově 73,4\%) s vlastní úrovní řídicích dovedností spokojeny. Na otázku, kde získali znalosti z oblasti řízení lidských zdrojů, respondenti odpověděli, že nejčastěji v praxi (37,1\%, 410 odpovědí). V případě získání znalostí ze školy převažovala střední zdravotnická škola. Na tuto odpověd' však mělo vliv i nejvyšší dosažené vzdělání cílových skupin. 
Kladně lze rovněž hodnotit zvýšený zájem staničních i vrchních sester o další vzdělávání v oblasti managementu. Naopak téměř 80 \% zdravotních sester v budoucnu nechce řídit lidi a dosáhnout pozice své nadřízené staniční nebo vrchní sestry. To rovněž uvedly také staniční sestry (66,7\% případů), které již v rámci svého povolání řídí své podřízené.

Celkové hodnocení manažerských kompetencí dle provedeného dotazníkového šetření je kladné a pozitivní. Manažerské kompetence jsou dle výsledků výzkumu u vrchních i staničních sester na dobré úrovni. V odpovědích dle jednotlivých nemocnic nebyly velké rozdíly a odpovědi se téměř shodovaly. I přes kladné celkové hodnocení by se však sestry na řídicích úrovních měly dále vzdělávat v oblasti managementu.

Mezi vybranými proměnnými (pracovní pozice, nejvyšší vzdělání, délka praxe a styl vedení) u staničních a vrchních sester nebyla na základě vypočtených koeficientů zjištěna závislost. Středně silná závislost je pouze mezi proměnnými pracovní pozice a preference komunikačních vztahů $\left(\chi^{2}=\right.$ 17,6305, p-value =0,0001, Fi =0,3801, Cramer V=0,3801, Pearson coefficient of contingence =0,3553). Staniční sestry jednoznačně preferují neformální vztahy, vrchní sestry nejsou vyhraněny, polovina preferuje formální a druhá část neformální vztahy na pracovišti. Stř̌edně silná závislost byla zjištěna u staniční sestry, která se vyjadřovala ke stylu řízení vrchní sestry a spokojenosti s výkonem jejího povolání $\left(\chi^{2}=53,9777\right.$, p-value =0,0000, Fi =0,6942, Cramer V=0,4008, Pearson coefficient of kontingence $=0,5703)$. Staniční sestry se ve většině případů vyjádřily, že u vrchních sester převažuje liberální styl ř́izení, se kterým jsou spokojeny.

management, kompetence, řízení lidí, vzdělávání, řídící dovednosti, kvalifikační požadavky, zdravotnictví, dotazníkové šetření

This paper is a part of solution of research plan MSM 6215648904 „Czech economy in the process of integration and globalization and development of the agricultural and service sectors in the new conditions of integrated European market".

\section{SUMMARY}

Skills and knowledge from the soft skills together with management skills are increasingly important today. This paper deals with managerial competencies of workers in health care. These were nurses and staff in management position at the middle and lower management level in public hospitals. There were cited papers and publications of Czech authors which deal with this topic in theoretical part of this paper. Very interesting is research from Bártlová (2006b). She researched the area of nursing management cooperation of health care management employees.

The range of higher education achieved does not differ greatly in the hospitals analysed. High school education predominated (in average around 80\%) in the case of nurses, department nurses and head nurses as well. The ratio of nurses with university degree is according this research very small and it will be very insufficient in future, because requirements for these management positions are increasing. The length of practice of the target nursing group is much better. More then $70 \%$ nurses have working practice in health care of more then 5 years. Working relationships in hospital have an informal character agree both nurses and head and department nurses in all hospitals. Nurses in management positions added that in $81.1 \%$ cases (103 nurses) prefer informal relations during communication with their subordinates. In communication between department nurses with head nurses the situation was very similar but 36.1\% (41 department nurses) prefer a formal style of communication. The managerial style of department nurses is, according to the opinion of nurses in $67.7 \%$ cases (595 nurses) democratic. On this statement agree head and department nurses who said that they use a predominately democratic managerial style (87.2\%, 109 head and department nurses). Nurses and department nurses are satisfied with the management skills of their superiors. Department and head nurses in selfevaluation questionnaire said that are in the most cases satisfied with own level of management skills (totally $73.4 \%$ department and head nurses).

On the question of where they obtained knowledge of human resources management 37.1\%, 410 nurses answers mostly in practice. In the case management in the school education high school predominated. These answers influenced the higher achieved education of the target groups.

We can appreciate in very positive way the higher interest of head and department nurses for next courses and education in management. On the other hand almost $80 \%$ nurses don't want to manage people in future and do not want to reach the position of department nurse or head nurse. This statement had department nurses (66.7 \% cases) as well, despite the fact that they manage subordinates. Finally evaluation of management competencies of department nurses and head nurses according this questionnaire research is very positive. Management competencies are according results of this research by head and department nurses on the good level. There aren't big differences in the answers from hospitals and the statistic results were very similar. Though head and department nurses 
judge their managerial competences positivel, nevertheless they should undertake further education in management.

Among chosen variables (working positron, the highest education, years of practice, and managerial style) by department and head nurses wasn't found dependence. There is only middle strong dependence between variables working position and preferencies of communitations' relationships $\left(\chi^{2}=\right.$ 17.6305, p-value $=0.0001, \mathrm{Fi}=0.3801$, Cramer V =0.3801, Pearson coefficient of contingence $=0.3553$ ) Department nurses prefer informal relationships, head nurses aren't pronounced, half of them prefer formal relationships, others informal relationships. There was found middle strong dependence by department nurses between managerial style of head nurse and satisfaction with their working output $\left(\chi^{2}=53.9777\right.$, $p$-value $=0.0000, \mathrm{Fi}=0.6942$, Cramer $\mathrm{V}=0.4008$, Pearson coefficient of contingence $=0.5703)$. Department nurses in most cases wrote that liberal managerial style predominates by head nurses and they are satisfy with this.

\section{REFERENCES}

BÁRLTOVÁ, S., 2006: Pracovní vztahy a kompetence všeobecných sester v ČR In: Sborník príspèvkü z konference s mezinárodní účastí „Zmèny v roli sestry na počátku nového tisíciletí." l. vyd. Brno: Národní centrum ošetřovatelství a nelékařských zdravotnických oborů, 208 s. ISBN 80-7013-449-6.

BÁRLTOVÁ, S., 2006: Stručný přehled výsledků výzkumu „Změny v roli sestry na počátku nového tisíciletí“. In: Sborník príspèvkư z konference s mezinárodní účastí „Zmèny v roli sestry na počátku nového tisíciletí." l. vyd. Brno: Národní centrum ošetřovatelství a nelékařských zdravotnických oborů, 208 s. ISBN 80-7013-449-6.

BODISON, W. G., 2006: Jak dosáhnout excelence ve zdravotnictví, Moderní rízení [on-line]. poslední revize 11. 5. 2006 [cit.2007-10-31]. Dostupné z: <http://modernirizeni.ihned.cz/3-18424750zdravotnictv\%ED-600000_d-0c >.

EXNEROVÁ, S., 2006: Komunikace pro „zdravotní sestry." 1 . vyd. Liberec: Technická univerzita v Liberci. 146 s. ISBN 80-7372-096-5.

KOŠTURIAK, J., 2007: Hodnota pro zákazníka ve zdravotnictví. Moderní řízení, 2007, ročník 42, č. 9, strana 12-16. ISSN 0026-8720.

KOTRBA, T., 2006: Klasifikace a komparace prahových kompetencí. In: MendelNet 2006. Sekce 5: Management. Mendelova zemědělská a lesnická univerzita v Brně: Brno, ISBN 80-86851-62-1.

KOTRBA, T., 2007: Manažerské kompetence zdravotnického personálu. In: sborník prací z 2. mezinárodní védecké konference Nové trendy - nové nápady 2007. Sekce: Marketing, management. Soukromá vysoká škola ekonomická Znojmo:Znojmo, strana 32-39, ISBN 978-80-903914-1-3.

KOTRBA, T., 2008: Management na lékařských fakultách a odborných zdravotnických školách. In: Sborník z mezinárodnívédeckékonference Firma a konkurenční prostředí 2008. 2. část, Sekce 3: Management v novém prostředí. Mendelova zemědělská a lesnická univerzita v Brně: Brno, strana 53-59, ISBN 978-80-7392-021-0.

KOTRBA, T., RAK, M., 2008: Specifika řízení kariéry
veveřejnémsektoru.In:MezinárodníBatovakonference pro doktorandy a mladévédecké pracovníky 2008. Sekce: Management. Univerzita Tomáše Bati ve Zlíně: Zlín, strana 229-227, ISBN 978-80-7318-664-7.

KVAPILOVÁ, M., JOBÁNKOVÁ, M., 2006: Nesoulad profesních a funkčních kompetencích jako zdroj pracovní zátěže In: Sborník príspěvků z konference s mezinárodní účastí „Zmèny v roli sestry na počátku nového tisíciletí." l. vyd. Brno: Národní centrum ošetřovatelství a nelékařských zdravotnických oborů, 208 s. ISBN 80-7013-449-6.

LÁMAL, J., BELLOVÁ, J., 2005: Ekonomika zdravotnictví. 1. vyd. Brno: Národní centrum ošetřovatelství a nelékařských zdravotnických oborů, 206 s. ISBN 80-7013-429-1.

PRYMULA, R., BERAN, J., ANTOŠ, K., 1999: Vybrané kapitoly ze zdravotnického managementu. 1. vyd. Hradec Králové: GAUDEAMUS, 158 s. ISBN 80-7041-243-7.

PRYMULA, R., BERAN, J., ŠPLIŇO, M., ANTOŠ, K., 1995: Základy managementu ve zdravotnictví II. Zdravotnické systémy. 1. vyd. Hradec Králové: Vojenská lékařská akademie Jana Evangelisty Purkyně, 131 s. ISBN 80-85109-99-9.

SOUČEK, Z., 2007: Efektivita nemocnic, Moderní rízení [on-line]. poslední revize 8. 11. 2007 [cit.2008-4-1]. Dostupné z: 〈http://modernirizeni.ihned.cz/3-22378480-zdravotnictv\%ED600000_d-fl $>$.

SOUČEK, Z., 2007: Management zdravotnických zařízení, Moderní ř́zení [on-line]. poslední revize 7. 9.2007 [cit.2007-10-31]. Dostupné z: <http:// ihned.cz/c4-10041240-21959760-000000_dmanagement-zdravotnickych-zarizeni>.

SOUČEK, Z., 2007: Problémy řízení zdravotnictví. Moderní ř́zení, 2007, ročník 42, č. 9, strana 8-11. ISSN 0026-8720.

TRUNEČEK, J., 2006: Kulatý čtverec českého zdravotnictví, Moderní ř́zení [on-line]. poslední revize 9. 2. 2006 [cit.2007-10-31]. Dostupné z: <http://modernirizeni.ihned.cz/index.php? $\mathrm{sl}=6 \& \mathrm{~s} 2=0 \& \mathrm{~s} 3=0 \& \mathrm{~s} 4=0 \& \mathrm{~s} 5=0 \& \mathrm{~s} 6=0 \& \mathrm{~m}=\mathrm{d} \&$ article[id] $=17772900>$.

Address

Ing. Tomáš Kotrba, Ústav managementu, Mendelova zemědělská a lesnická univerzita v Brně, Zemědělská 1 , 61300 Brno, Česká republika, e-mail:xkotrba@node.mendelu.cz 